\title{
Experimental study of Food Court Waste air gasification process performances in a batch reactor
}

\author{
Raluca Nicoleta Tîrtea, Gabriela Ionescu*, Cora Bulmău and Cosmin Mărculescu \\ University Politehnica of Bucharest, Department of Energy Production and Use, \\ Splaiul Independenţei 313, Romania
}

\begin{abstract}
The paper presents the experimental results of Food Court Waste air gasification using a batch reactor. This type of waste is generated mainly in the food court areas of services spaces, shopping centers, airports and malls and is generally composed of paper \& cardboard, plastic, organic, wood, metal and glass waste. The process operating parameters were: temperatures between $650^{\circ} \mathrm{C}$ and $850^{\circ} \mathrm{C}$ and an equivalent ratio of 0.25 and 0.4 respectively. The study focused on the influence of process parameters on the energy conversion rate considering the cold gas and hot gas efficiency correlated with the feedstock carbon conversion rate. The recorded instantaneous concentrations of sampled gas species were plotted in time dependent graphs for accurate variation curves of gases concentrations. The results can be used to isolate the startup stage of the gasification process and to establish the optimal process parameters for increased overall energy efficiency. In conclusion, considering the current setup, operational parameters and process energy efficiency, the optimal temperature for the air gasification of Food Court Waste is $850^{\circ} \mathrm{C}$ with an equivalent ratio of 0.40 .
\end{abstract}

\section{Introduction}

Presently, the global municipal solid waste (MSW) generation accounts for 1.3-1.9 billion tonnes per year and is forecasted to increase to 2.2 billion tonnes, by 2025 [1]. The necessity of waste recovery in the form of secondary raw material or energy production represents a worldwide priority in the renewable sources' management field. The EU strategic long-term vision for 2050 to a novel, self-sustained conversion chain, and climateneutral economy includes ascending common key targets such as $65 \%$ recycling of municipal waste and $70 \%$ of packaging materials by 2035, and 2030 respectively, correlated with a maximum landfilling rate of $10 \%$ of MSW [2]. However, the transition towards the circular economy concept and its design still accounts a demanding moving from theory to practical implementation, by adapting industrial processes.

The complexity of the treatment choice is dictated firstly by the waste structure, composition and properties, engaged as stand-alone fractions (e.g. biomass, plastic) or in

\footnotetext{
* Corresponding author: gabriela ionescu@ymail.com
} 
mixtures (e.g. MSW, solid recovered fuel) [3-5]. On average, the share of combustible materials in MSW is about 70-80\% making it suitable for thermochemical recycling [6-8]. Combustion is the preferred waste treatment technology followed by gasification [9]. The chemical recycling, via contemporary methods (pyrolysis and gasification) offer prominent waste management with environmental benefits [10,11]. During thermal treatment, the syngas produced during the process can be used for heating and power generation. The conversion and energy efficiency of the gasification process can be evaluated based on the quality of the syngas obtained which depends mainly on: volumetric composition and flow rate, gasifying agent (the ratio of oxidant to fuel) and characteristics of the conversion process (process temperature and pressure, residence time, reactor type) [12-15].

The feedstock used in our experiments was food court waste (FCW). The waste is mainly produced in the food court areas of services spaces, shopping centers, airports and malls. The feedstock is composed of paper \& cardboard, plastic, wood, metal and glass that represents the main source of packaging, along with the disposable cutlery and dishes. To all these, organic waste can be added. The composition of the FCW can be broadly different depending on the type of food court area where it is produced, season, weekday and time of the day. Over time, the combustible fractions of FCW (paper, cardboard, plastic, organic waste and wood) have been studied individually [16-24] as well as in various mixtures [2528], as feedstock for thermochemical conversion purpose.

The aim of the current research is to determine the influence of operating parameters on the process energy conversion rate based on cold gas and hot gas efficiency corelated with the feedstock carbon conversion rate.

The recorded instantaneous concentrations of sampled gas species were plotted in time dependent charts for accurate variation curves of gases concentrations. The results can be used to isolate the startup stage of gasification process and to establish the optimal process parameters for increased overall energy efficiency.

\section{Material and methods}

\subsection{Material}

The material used in the present experimental study has a typical composition of the FCW feedstock. The details regarding the selection criteria and collection steps were previously reported in other already published papers of the research group [29].

Briefly, to establish an equivalent composition of waste to work with, waste samples were collected from three different locations during different times of day and week. For its energetic valorization, the waste was sorted by components, non-combustible fractions such as glass and aluminum cans packaging, have been removed, while the combustible ones have been dried, grounded and homogenized in specific proportions. The composition of FCW and its properties are presented in the next table.

Table 1. Properties of food court waste [29]

\begin{tabular}{|c|c|c|c|}
\hline & & Unit & Value \\
\hline \multirow{5}{*}{ 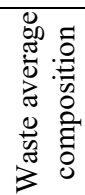 } & Paper & $\%$ & 29.29 \\
\hline & Cardboard & $\%$ & 26.22 \\
\hline & Plastic & $\%$ & 18.92 \\
\hline & Organic residues & $\%$ & 25.18 \\
\hline & Wood & $\%$ & 0.39 \\
\hline \multirow{3}{*}{ 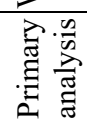 } & Moisture & $\%$ & $26.12^{\text {as }}$ \\
\hline & Volatile matter & $\%$ & $80.89^{\mathrm{db}}$ \\
\hline & Fixed carbon & $\%$ & $7.97^{\mathrm{db}}$ \\
\hline
\end{tabular}




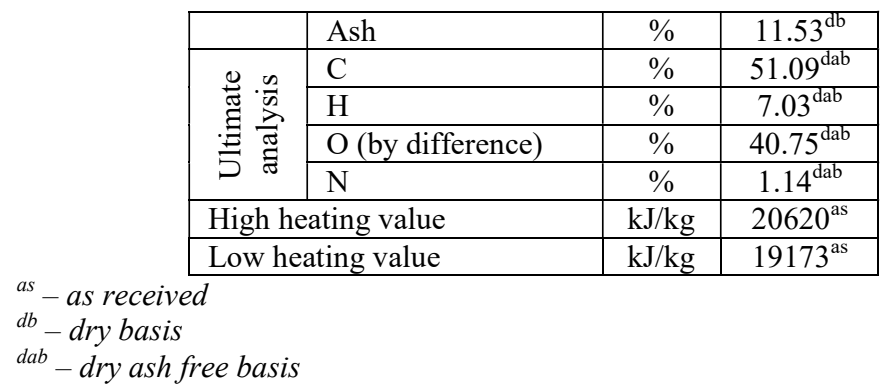

\subsection{Methods}

Air gasification experiments were carried out in a batch tubular electrically heated reactor. The reactor is specially designed to simulate thermochemical conversion experiments of solid organic material in a batch mode using a custom made tubular electric oven, produced by NABERTHERM, model RO 60/750/13.

The design of the FCW air gasification process in the batch tubular reactor is shown in Figure 1.

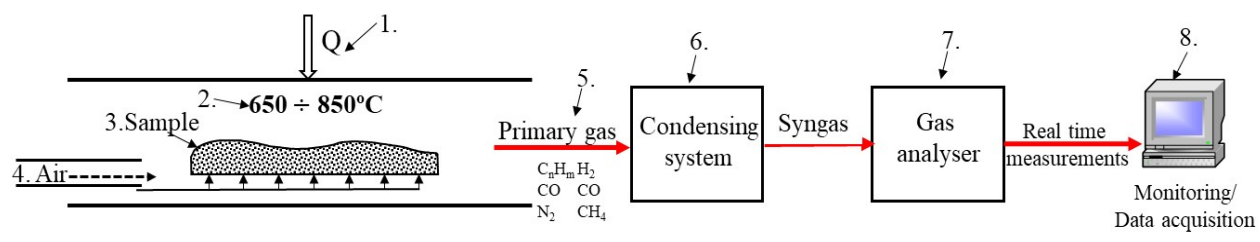

Figure 1. Air gasification process experimental set-up (adopted after 30-34)

1. Externally heated batch reactor; 2. Temperature controller; 3. Food Court Waste sample; 4. Inlet air flow meter; 5. Gas line outlet (primary gas); 6. Cooling systems with watercooled ice; 7. Testo $350 \mathrm{XL}$ gas analyser; 8. Data monitoring and acquisition: EASYemission software, Testo, Inc.

A detailed presentation of the reactor main geometrical characteristics and potential configurations and runs, along with the transitory regime's mechanism are presented in previous papers of the authors [31-34]. Briefly, in the experimental runs the batch reactor (1.) was electrically heated at temperatures between $650^{\circ} \mathrm{C}$ and $850^{\circ} \mathrm{C}$ (2.). The $\mathrm{FCW}$ sample was distributed along the active zone of the crucible and then inserted in the preheated batch reactor (3.). The air was introduced in co-current flow and kept constant using a flowmeter (4.). To ensure a constant amount of air in the reactor and process duration, the amount of air needed to gasify $10 \mathrm{~g}$ of sample at an equivalent ratio (ER) of 0.25 was computed $\left(15.881_{\text {air }}\right)$. Then, considering the amount of air resulted for the first case, the amount of sample was calculated so that the air/fuel ratio for an ER of 0.40 to be assured. The primary gases formed during the process (5.) were passed through a condensing system with water-cooled ice (6.). In order to establish the transitory regimes, the gases produced were analyzed in real time using the Testo 350 XL gas analyzer (7.) and monitored, registered respectively in a continuous mode with EASY- emission software, Testo, Inc (8.).

The conversion and energy efficiency of the gasification process have been calculated considering three factors: Carbon conversion efficiency - CCE; Cold-gas efficiency - CGE; 
Hot-gas efficiency - HGE according to [13-15, 35,36]. The formula used to compute the three mentioned parameters are described in another research by the same authors [30]. Briefly the CCE was determined using two methods. In the first method the amount of syngas produced determined by mass balance is considered (1), while in the second one the amount of syngas produced determined by calculation based on the amount of nitrogen introduced into the gasification process and the concentration of nitrogen measured in syngas produced.

\section{Results and discussions}

To evaluate the process in terms of gas quality, the variation concentration of the most important combustible gas species (carbon monoxide and hydrogen) according to process parameters were analyzed. In figures 2 and 3 , the $\mathrm{CO}$ and $\mathrm{H}_{2}$ concentration as function of the FCW air gasification parameters (temperature and ER) are presented. According to the figures below, gas species concentrations increase with temperature rise, but decrease when ER increases. The reduction of the combustible gas species concentration from the primary syngas at higher ER could be a consequence of air quota increase in the process. As ER increases, more air is introduced in the reactor, therefore, more Nitrogen is present in the reactor, and thus in the produced gas.

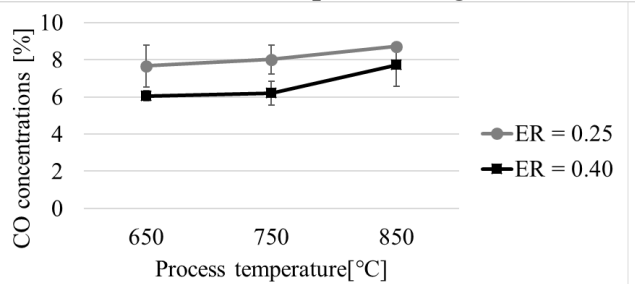

Figure 2. Variation of $\mathrm{CO}$ concentration - air FCW gasification

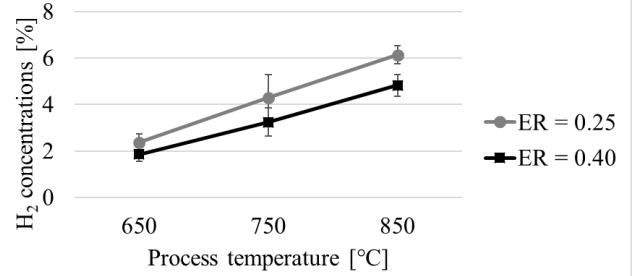

Figure 3. Variation of $\mathrm{H}_{2}$ concentration - air FCW gasification

To evaluate the gasification processes in terms of conversion and energy efficiency, CCE, CGE and HGE were computed for each experimental configuration studied. Depending on computation method, two values of CCE resulted [13-15,36]. In Figure 4 and Figure 5 the variation of $\mathrm{CCE}$ in $\mathrm{FCW}$ air gasification as function of the process parameters is presented. In both cases, CCE increase with process temperature rise, for the studied range. Best results are obtained at $850^{\circ} \mathrm{C}$ and ER of 0.40 . Depending on the calculation method applied, results may differ by 16 percentage points.

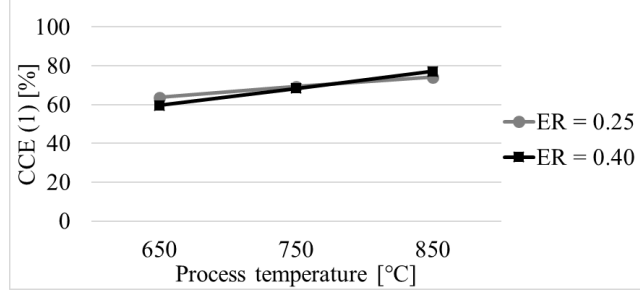

Figure 4. CCE (1) - FCW air gasification

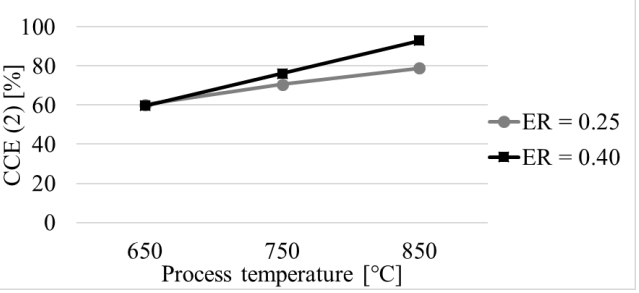

Figure 5. CCE (2) - FCW air gasification

In figures below are presented the values of process energy efficiencies obtained for air gasification of FCW at different process parameters. CGE and HGE increase with temperature and ER. 


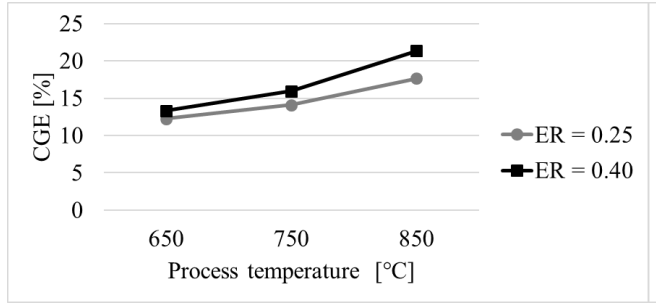

Figure 6. CGE - FCW air gasification

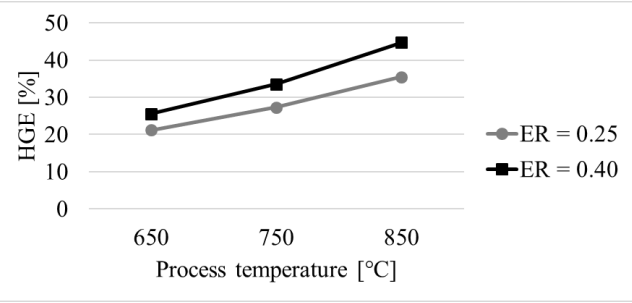

Figure 7. HGE - FCW air gasification

At the same process temperature, the increase of ER by 0.15 leads to CGE and HGE increase by up to 4 and 9 percentage points, while the process temperature increase by $200^{\circ} \mathrm{C}$ leads to energy efficiencies rise by 5-8 and 14-19 percentage points. Best CGE and HGE results are obtained at $850^{\circ} \mathrm{C}$ and ER of 0.40 .

\section{Conclusions}

Based on the experimental results, the FCW air gasification leads to a syngas production more than $95 \%$. The amount of the syngas produced is appropriate due to the easily flammable feedstock properties, that is mainly composed of lignocellulosic and polymerbased material accounting for $75 \%$ from the total amount of FCW analysed. As expected, the syngas production is strongly influenced by the process temperature. With the augmentation of the process temperature, the overall conversion efficiency of the feedstock into gas increases. In all the experimental results the CCE tends to increase and being directly proportional with the temperature and ER with their increase. The enhancement of process temperature leads to the augmentation of the reaction rates. The increase of the air used in the process assures more oxygen supplied in the reactor and therefore further carbon oxidation reactions might occur.

Due to the experimental setup performed in batch mode the CGE and HGE values obtained are small in comparison with standard gasification processes. Thus, in this case, the gasification process doesn't fully complete its cycle. Generally, the difference between CGE and HGE in a typical gasification process is about $10-20$ percentage points $[13,14]$. However same trends are registered along the CGE and HGE values obtained.

Therefore, the values of the energy efficiency are determined considering the intermediate syngas composition that reflects certain sequences of the gasification process and not the entire one. The present energy efficiencies values can give a reliable and comprehensive view on the gasification process transition stages, corelated with temperature and ER influence on the obtained gas composition.

In conclusions, for the air gasification of $\mathrm{FCW}$, considering the process energy efficiencies the optimal process temperature is $850^{\circ} \mathrm{C}$ and $\mathrm{ER}=0.40$.

\section{ACKNOWLEDGMENT}

Funding provided through Romania's "Competitiveness Operational Programme 2014-2020" Priority Axis 1: Research, Technological Development and Innovation (RD\&I) to Support Economic Competitiveness and Business Development Action 1.1.4. Attracting high-level personnel from abroad in order to enhance the RD capacity ID/Cod My SMIS: P_37_768/103651; No. Contract: $39 / 02.09 .2016$ 


\section{References}

1. E. C. Rada, L. I. Cioca, G. Ionescu, MATEC Web of Conferences 121, 8, (2007)

2. European Commission, https://ec.europa.eu/clima/policies/strategies/2050, Accessed in March 2019.

3. G. Ionescu, C. Bulmău, E3S Web of Conferences 85, 6 (2019)

4. G. N. Sava, G. Ionescu, H. Necula, M. Scripacriu, M. Q. Duong, S. Leva, M. Mussetta, 2017 IEEE International Conference on Environment and Electrical Engineering and 2017 IEEE Industrial and Commercial Power Systems Europe (EEEIC/I\&CPS Europe), 1-5 (2017)

5. E. C. Rada, G. Ionescu, F. Conti, U. I. Cioca, V. Torretta, Calitatea 19(167), 118-122 (2018)

6. E. C. Rada, M. Ragazzi, V. Torretta, G. Castagna, L. Adami, L. I. Cioca, AIP Conference Proceedings 1968, 030050-1- 030050-6 (2018)

7. S. Chen, A. Meng, Y. Long, H. Zhou, Q. Li, Y. Zhang, Journal of the energy institute 88(3), 332-343 (2015)

8. E. Ranieri, G. Ionescu, A. Fedele, E. Palmieri, A. C. Ranieri, V. Campanaro, Waste Management \& Research 35(8), 890-898 (2017)

9. H. A. Gabbar, M. Aboughaly, N. Ayoub, Journal of the Energy Institute 91(4), 481488 (2018)

10. S. Ciuta, F. Patuzzi, M. Baratieri, M. J. Castaldi. Journal of Analytical and Applied Pyrolysis, 108, 316-322, (2014).

11. M. S. Ciuta, C. Marculescu, , C. Dinca, A. Badea (2011). UPB Sci. Bull, 73, 307-320.

12. R. N. Tîrtea, C. Mărculescu, A. Badea, University Politehnica Of Bucharest Scientific Bulletin Series C-Electrical Engineering And Computer Science 79(1), 315-322 (2017)

13. C. Higman, M. van der Burgt, Gasification, Gulf Professional Publishing, 2008

14. P. Basu, Biomass gasification, pyrolysis and torrefaction: practical design and theory. Academic press, 2013.

15. C. Stevens, Thermochemical processing of biomass: conversion into fuels, chemicals and power. Ed. Robert C. Brown. John Wiley \& Sons, 2011.

16. P. A. Caton, M. A. Carr, S. S. Kim, M. J. Beautyman, Energy Conversion and Management 51.6, 1157-1169 (2010)

17. C. Wu, P. T. Williams, Fuel 89.10, 3022-3032 (2010)

18. R. Xiao, B. Jin, H. Zhou, Z. Zhong, M. Zhang, Energy Conversion and Management 48.3, 778-786, (2007)

19. C. M. van der Meijden, H. J. Veringa, L. PLM Rabou, Biomass and bioenergy 34.3, 302-311 (2010)

20. I. Ahmed, A. K. Gupta, Applied Energy 86.9, 1732-1740 (2009)

21. I. Ahmed, A. K. Gupta, Applied energy 86.9, 1813-1821 (2009)

22. P. N. Sheth, B. V. Babu, International Journal of Hydrogen Energy 35.19, 10803$10810(2010)$

23. G. Lopez, M. Artetxe, M. Amutio, J. Alvarez, J. Bilbao, M. Olazar, Renewable and Sustainable Energy Reviews 82, 576-596 (2018)

24. R. Muangrat, J. A. Onwudili, P. T. Williams, Bioresource technology 101.17, 6812$6821(2010)$

25. I. I. Ahmed, N. Nipattummakul, A. K. Gupta, Applied energy 88.1, 165-174 (2011)

26. I. Ahmed, A. K. Gupta, Applied Energy 86.12, 2626-2634 (2009)

27. K. G. Burra, A. K. Gupta, Applied Energy 211, 230-236 (2018)

28. F. Pinto, C. Franco, R. N. Andre, M. Miranda, I. Gulyurtlu, I. Cabrita, Fuel 81.3, 291297 (2002) 
29. I. Stănciulescu, , C. Mărculescu, D. Boldor, 2018 IEEE International Conference on Environment and Electrical Engineering and 2018 IEEE Industrial and Commercial Power Systems Europe (EEEIC/I\&CPS Europe), 1-4 (2018)

30. Tirtea R.N., Bulmau C., Ionescu G., Marculescu C., The initiation stage of Food Court Waste air versus steam gasification processes, TE-RE-RD 2019, eISSN: 2267-1242), under review.

31. R. N. Tîrtea, C. Mărculescu, A. Badea, 2015 International Conference on ENERGY and ENVIRONMENT (CIEM) (2015)

32. C. Bulmău, C. Mărculescu, S. Lu, Z. Qi, Journal of Geochemical Exploration 147, 298-305 (2014)

33. C. Mărculescu, S. Ciuta, Renewable energy 57, 645-652 (2013)

34. R. N. Tirtea, I. Stanciulescu, G. Ionescu, C. Bulmau, C. Marculescu, D. Boldor, 2017 International Conference on ENERGY and ENVIRONMENT (CIEM), 390-393 (2017)

35. M. L. de Souza-Santos, Solid Fuels Combustion and Gasification: Modeling, Simulation. CRC Press, 2010.

36. W. De Jong, J. Ruud van Ommen, Biomass as a sustainable energy source for the future: Fundamentals of conversion processes. John Wiley \& Sons, 2014 